Jeffrey $D$. Karrenbrock was an economist at the Federal

Reserve Bank of St. Louis when this paper was written. David

$H$. Kelly provided research assistance.

\title{
The Behavior of Retail Gasoline Prices: Symmetric or Not?
}

程 INCE DEREGULATION in the early $1980 \mathrm{~s}$ crude oil prices have been allowed to move freely with market conditions. Because of oil supply shocks and seasonal movements in gasoline demand, retail gasoline prices often fluctuate more widely than consumer prices in general. Some analysts and politicians have criticized these retail gasoline price movements, alleging that they do not respond symmetrically to price changes at earlier stages of the marketing chain. In particular, they believe that retail gasoline prices do not reflect decreases in oil and wholesale gasoline prices as rapidly and fully as they do price increases. The shaded insert on page 20 contains comments typical of this line of criticism. The perceived asymmetry in retail gasoline price movements is of special concern to consumers who believe that they are being "gouged" by the oil industry.

Much of the perception of possible asymmetry focuses on the relationship between the price of ofl and the retail price of gasoline. This suggests that oil producers or Fefineries are principally responsible for the asymmetry. In fact, a survey undertaken by the American Petroleum Institute concluded that 80 percent of Americans believed that oil companies artificially raised the price of gasoline after Iraq's invasion of Kuwait on August $2,1990 .{ }^{1}$ This statistic suggests that many Americans believe retail gasoline stations are owned and operated by the oil refiners. In some cases this is true, but much of the gasoline sold at the retail level is sold through out* lets that are not owned by the oil producers and refiners. The fact that many retail outlets are "independent" suggests that they have some autonomy in setting the retail price. The role these retailers play in the perceived asymmetry is largely ignored, even though they are as much a possible source of such an asymmetry as are the oil producers and refiners. ${ }^{2}$ This article analyzes the role that retailers may play in the perceived asymmetric movement of retail gasoline prices. Specifically, we test whether

'McKenzie (1991).

zAn article by Solomon (1990), however, does point out the potential role of retail outlets. See "Gasoline Prices Resist Crude Behavior." 


\section{What Goes Up Need Not Come Down?}

"Those who are doing the gouging will hear from the president: - Treasury Secretary Nicholas Brady. The Wall Street Journal, (Shribman and Mcoueen) August 9, 1990 .

"Retail (gasolinel prices go up much faster than they come down" - a spokesman for the Automobile Association of America. The Wall street Journal, (Solomon) August 9, 1990.

Pump prices are fast to respond to rising prices but slower to fall when crude prices fall" - Antonio Szabo, oil consultant with Bonner \&: Moore. The Wall Street Journal. (Business Bulletin) August $3,1989$.
"Whenever oil prices fall, there is always this stickiness in gasoline prices on the way down. You never see this stickiness on the way up." -Ed Rothschild energy expent at Citizen Action. New York Times, (Wald) July 2, 1990.

When crude prices go up, product prices tend to rise with crude prices. But when crude prices go down, product prices tend to lagthey go down slowly? - John Hitton, oil in. dustry analyst for Argus Research Corp. St. Louis Post-Dispatch, (Crudele) June 19, 1990. wholesale gasoline price increases are passed along to the retail customer more fully and rapidly than are wholesale gasoline price decreases.

\section{GASOLINE DISTRPBTION, PRICING AND MARGINS}

The purchase of gasoline at the retail pump is the end of a long and complicated marketing chain. A simplified illustration of how oil, after undergoing refining, reaches the consumer as gasoline is shown in figure 1 . From the oil fields, oil is moved to the refineries either by tanker, pipeline, or a combination of the two. The refinery receiving the oil may be owned by the company that produced the oil or may be independent. On January 1, 1990, 205 U.S. refineries, owned by over 100 companies, were in operation.

At the refinery, oil is distilled into a variety of products including gasoline, home heating oil, diesel oil, jet fuels, asphalt, kerosene and lubricants. One barrel of oil (42 U.S. gallons) yields about 43 percent gasoline, ${ }^{3}$ Gasoline is transported from the refinery by truck, pipeline, tanker or barge. Some is moved directly from the refinery to retail outlets; some is moved from the refinery to terminal storage areas closer to final consumption. From these storage areas, the gasoline is generally moved to the point of final sale by truck. Once the gasoline reaches its final destination before purchase, it is usually stored in large underground tanks.

Refiners may sell gasoline directly to "end users" such as large trucking firms, industrial manufacturers and utilities. They may also sell directly to retail gasoline outlets. Retail gasoline stations owned by the refining company are classified as "end users." Retail gasoline stations not owned by refining companies are known as "independents." As figure 1 shows, sales to end users accounted for about 19 percent of refiners' gasoline sales, by volume, in 1988, with 17 percent of the sales to company outlets and 2 percent to other end users.

The other 81 percent of refiners' gasoline sales are made to either "jobbers" or independent retail outlets. Jobbers purchase gasoline from the refiners which they in turn sell and distribute to retail stations and large users. Gasoline sales made by refiners to the non-companyowned retail outlets and to jobbers are referred to as "sales for resale."

Several different entities are involved in the pricing of gasoline as it is moved from the oil field to the retail gasoline outlet. When oil is sold to the refinery, the price for this transaction is called the producer price. The price charged for gasoline by the refiner or jobber to 
Figure 1

\section{Oil and Gasoline Distribution Channels}

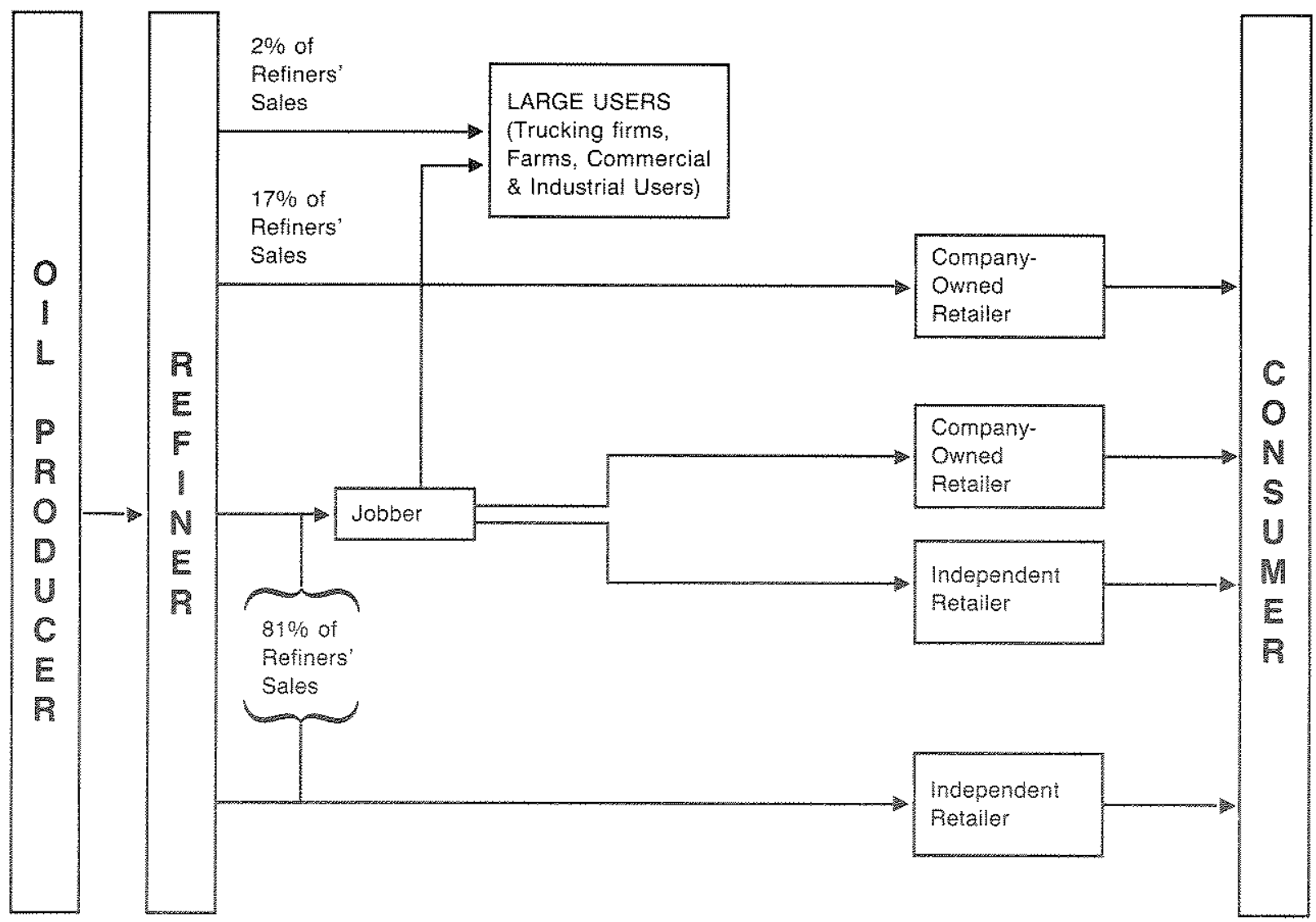

1. Based, in part on information provided in Dougher and Jones (1990), p. 7.

the retail gasoline station is called the wholesale price. ${ }^{4}$ The price the gasoline station charges the consumer is called the retail price. The differences between prices at various levels in the marketing chain are called "margins." The difference between the retail and wholesale price is called the wholesale-retail margin. The difference between the wholesale price and pro ducer price is called the producer-wholesale margin. The overall difference is called the producer-retail margin.

4The price that the jobber pays the retiner is included in

the "sales for resale" price series used in this study. 


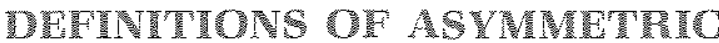

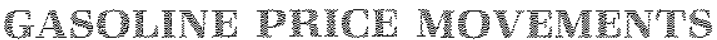

Retail price movements are defined as asymmetric if an increase in the wholesale price affects the retail price differently than an equalsized decrease. Three types of asymmetry are defined. The first deals with the length of time in which a wholesale price change works its way through to the retail level. For example, is an increase in the wholesale price passed along more quickly to the retail level than an equalsized wholesale price decrease?

The second type of asymmetry deals with the amount of a wholesale price change that passes through to the consumer. For example, does a 10-cent increase in the wholesale price lead to a 7.5-cent increase in the retail price, while a 10cent decrease in the wholesale price leads to only a 5 -cent decline in retail price?

The third type of asymmetry is a combination of time and amount. The pattern of retail price response may differ for wholesale price increases and decreases. Although the retail price may adjust to a wholesale price increase and decrease by an equal total amount and length of time, the amount of adjustment in each period may not be equal for price increases and decreases.

For example, in cases where the wholesale price increases and decreases 10 cents per gallon, retail prices may require two months to completely respond to both wholesale price changes. Assume the retail price increases and decreases 9 cents per gallon in response to the wholesale price increase and decrease, respectively. In such a situation, symmetry exists with respect to both the timing and amount of retail price movements. The pattern of the retail price response might be to increase (decrease) 7 cents in the initial month and increase (decrease) 2 cents in the month following a wholesale price increase (decrease). This pattern is symmetric. However, the pattern could be such that the retail price rises 7 cents and 2 cents in the first two months for a wholesale price increase, while the retail price falls only 3 cents in the initial month and 6 cents in the second month in response to a wholesale price decrease. This pattern is not symmetric.
Since producers, wholesalers and retailers all play a role in the determination of the retail price of gasoline, the perceived asymmetric price movements in the industry could be occurring between the producer and wholesale level or the wholesale and retail level. As noted earlier, many discussions of the perceived price asymmetry in the gasoline industry focus on the producer-retail price margin. Such a focus on the producer-retail margin tends to mask the role that retailers play in determining the producer-retail margin. Indeed, the perceived asymmetry may as readily be due to retailer behavior. In this case, simply observing the producer-retail price margin would not allow us to determine who is responsible for any asymmetry.

Price-movement asymmetry has been found to exist in several commodity markets, including oranges, lemons, dairy products, some fresh vegetables, pork and beef. In addition, the markup of price over cost in durable and nondurable manufacturing has been found to vary over the business cycle. ${ }^{5}$ Thus, a finding that price movement asymmetry exists in the retail gasoline market would not be unique. Many of the works cited above indicate the importance of industry concentration as a factor in explaining the existence of asymmetry in these markets. Kinnucan and Forker (1987) note that "because of industry concentration . . ., it is commonly asserted that middlemen use market power to employ pricing strategies which result in complete and rapid pass-through of cost increases but slower and less complete transmission of cost savings."

\section{GASOLINE PRECES AND CONSUMPTITON}

The U.S. average retail and wholesale prices of gasoline are shown in figure 2 for the period examined (January 1983 to December 1990). Several intervals of relatively large and rapid wholesale price changes are shown in the figure. In early 1986, following the collapse of oil prices, wholesale gasoline prices dropped sharply. In the spring of 1989 , gasoline prices rose sharply due "in part because of the temporary closing of the port of Valdez, Alaska, at the terminus of the Trans-Alaska pipeline, after the

5Pick et al (1990), Kinnucan and Forker (1987), Ward

(1982), Heien (1980) and Hahn (1990) all tind asymmetry in the agricultural markets. Domowitz et al (1988). Bils (1987) and Morrison (1988) find asymmetric markups in the manufacturing sector. 


\section{Figure 2}

\section{U.S. Average Retail and Wholesale Gasoline Prices'}

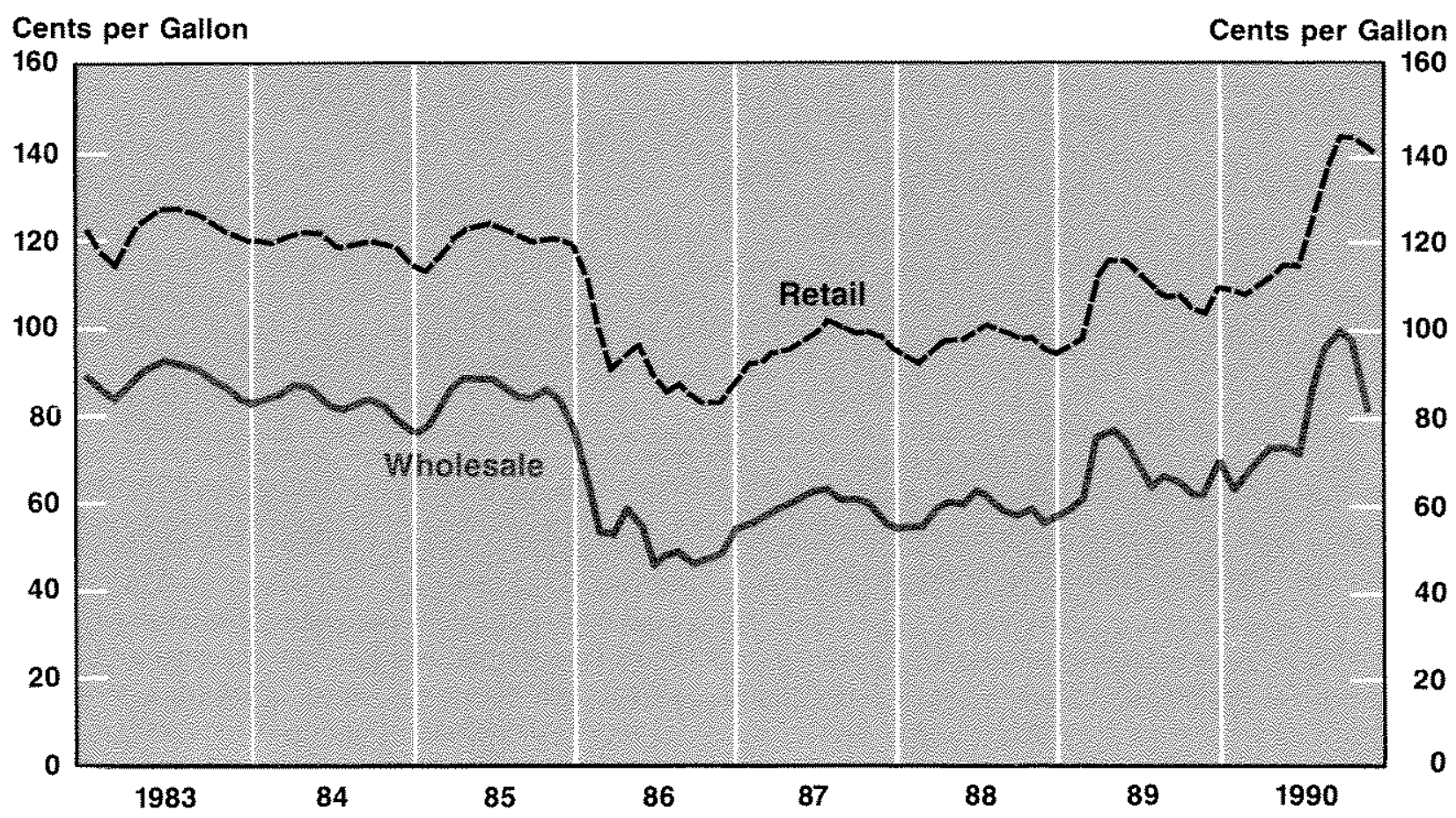

1Retail prices include federal and state tax.

Exxon Valdez oil spill in March." 6 The jump and subsequent decline in prices in late 1990 are associated with an OPEC oil price increase prompted by Iraq in late July 1990, the subsequent Iraqi invasion of Kuwait and the world embargo of Iraq.Kuwait oil. In all instances, the retail price appears to parallel the wholesale price quite closely. A more detailed and system. atic analysis is necessary to determine if there is indeed a symmetric response in retail prices to a wholesale price increase and decrease. Although not shown in figure 2 , the wholesale and retail prices of different grades of gasoline (premium, unleaded regular and leaded regular) also exhibit similar parallel movements with wholesale price changes.

Since the analysis below examines asymmetry for different gasoline grades, it is useful to note the relative importance of these fuels. The mix of different grades of gasoline has changed substantially during the last 30 years. Prior to 1975 , leaded gasoline accounted for over 50 percent of all motor gasoline fuel sales. Leaded gasoline's market share began to decline, however, after the enactment of environmental laws that required automobiles to burn unleaded gasoline and refiners to reduce the lead content of their

6See Wald (1990). 
gasoline. Today, leaded gasoline accounts for only about 17 percent of total motor gasoline consumption, while unleaded regular and premium gasoline account for 59 percent and 24 percent, respectively. ${ }^{7}$

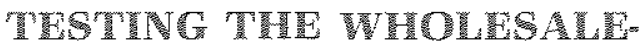

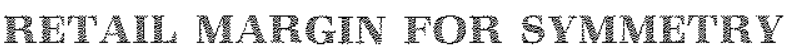

The hypothesis considered is that movement in the wholesale-retail margin in the gasoline market is symmetric. We test to see if decreases in wholesale gasoline prices are passed along to consumers as rapidly and as fully as are wholesale gasoline price increases. We test only for symmetry in the wholesale-retail price margin because the model used for this test may be best suited for this margin. The model assumes a markup method is used to set the retail price of gasoline. ${ }^{8}$

To test for symmetric movements in retail prices, we use a model in which the current retail gasoline price $\left(R_{t}\right)$ is a function of the wholesale gasoline price $\left(W_{1}\right)$; both prices are measured in cents per gallon. This relationship is summarized as

(1) $\mathrm{R}_{\mathrm{t}}=\mathrm{a}_{0}+\mathrm{a}_{1} W_{\mathrm{t}}$

The effect of a change in the wholesale price on the retail price is

(2) $R_{t}-R_{t-1}=a_{1}\left(W_{t}-W_{t-1}\right)$.

In order to examine how the affect of a wholesale price increase differs from that of a decrease, periods of wholesale price increases and decreases must be separated.

Following an approach similar to that developed by Wolfram (1971), this segmentation can be achieved using the model
(3) $\Delta \mathrm{R}_{\mathrm{t}}=\mathrm{a}_{1} W \mathrm{I}_{\mathrm{t}}+\mathrm{a}_{2} W \mathrm{D}_{\mathrm{t}}+\mathrm{e}_{\mathrm{t}}$

where

$$
\begin{aligned}
& \Delta R_{t}=R_{t}-R_{t-1} \\
& W I_{t}=W_{t}-W_{t-1} \text { if }\left(W_{t}-W_{t-1}\right)>0, \\
& \text { and }=0 \text { otherwise, } \\
& W D_{t}=W_{t}-W_{t-1} \text {, if }\left(W_{t}-W_{t-1}\right)<0, \\
& \text { and }=0 \text { otherwise, } \\
& e_{t}=\text { a random error term. }
\end{aligned}
$$

All $W \mathrm{I}_{\mathrm{t}}$ are positive or zero and all $W \mathrm{D}_{\mathrm{t}}$ are negative or zero. If retail prices respond symmetrically to wholesale price increases and decreases, then one would expect to find $a_{1}=a_{2}$. In order to allow for lags in adjustment time, a more general specification is

$$
\text { (4) } \Delta \mathrm{R}_{\mathrm{t}}=\mathrm{a}_{\mathrm{a}}^{\prime}+\sum_{\mathrm{i}=0}^{\mathrm{p}} \mathrm{a}_{\mathrm{i}, \mathrm{i}} W \mathrm{I}_{\mathrm{i}-\mathrm{i}}+\sum_{\mathrm{i}=0}^{\mathrm{q}} \mathrm{a}_{2, \mathrm{i}} W \mathrm{D}_{\mathrm{t}-\mathrm{i}}+\mathrm{e}_{\mathrm{t}}
$$

where $p$ and $q$ are the specified number of lags for the wholesale price increases and decreases, respectively ( $p$ need not equal $q$ ). An intercept, $a_{0}^{\prime}$, could be positive, negative or zero and need not be included on theoretical grounds. Following Heien (1980) and Boyd and Brorsen (1988), however, we include it to avoid biasing the coefficient estimates if the intercept is not truly zero. This variable captures the average influence of all other factors besides raw material price changes that influence the retail price. ${ }^{10}$

Differences in the timing of price pass-through would be indicated by differences in the number of lags for increases (p) and decreases (q). The test of interest for the amount of pass. through now becomes testing the equality $\sum_{i=0}^{\mathrm{B}} \mathrm{a}_{1, \mathrm{i}}=\sum_{\mathrm{i}=0}^{\mathrm{q}} \mathrm{a}_{2, \mathrm{i}}$, In other words, is the cumulative
7Based on volumes of first sales of motor gasoline in the Petroleum Marketing Annual [U.S. Department of Energy, (1988)], p. 216.

8This approach seems to more accurately represent the pricing behavior of retail outlets than oil refiners. Refiners with several oil products are perhaps more likely to employ a more sophisticated pricing mechanism than the retailer with a narrower range of oil products. One could make the argument, however, that retail outlets also have a mult:product pricing function, especially if the station is associated with a converience store. Dougher and Jones (1990) note suggestions that low margins on gasoline may be offset by higher margins on convenience foods.

9Wolfram's procedure uses the level of the dependent variable, while we use the first difference of the dependent variable. The model was also run for unleaded gasoline using the natural logs of all variables. The results are similar to those using the first-difference data.

10 In some studies, a variable to measure changes in other major marketing margin cost components, such as labor, transportation and packaging materials, has been included in equation 4. Preliminary estimates for this study that included transportation wages and/or service station wages showed that neither variable was statistically significant. 
effect of a wholesale price increase equivalent to that of a wholesale price decrease? If wholesale price changes are fully reflected in the retail price, we would expect to see $\sum_{i=0}^{p} a_{1, i}=1$ and $\sum_{i=0}^{\mathfrak{q}} a_{2, i}=1$. Symmetry in the pattern of retail price response cannot be rejected if $p$ equal $q$ and all $\mathrm{a}_{1, i}=\mathrm{a}_{2, \mathrm{i}}$.

\section{DATA AND RSTMMATON PROCDDURE}

January 1983 through December 1990, a period of relatively little government intervention. in the gasoline market, was chosen as the period of analysis. Honeycutt (1985) notes that a ". . factor that influenced gasoline marketing, beginning in August 1971 and continuing to January 1981, was extensive federal intervention in the marketplace. ${ }^{\prime 1}$ Furthermore, he notes that "statements by several major refiners that any changes in gasoline marketing would be phased in gradually suggest that not all important responses to decontrol had occurred by September 1981."12 In order to allow time for these "important responses" to have little or no effect on the results, the period studied here starts in January 1983. During the period analyzed, the number of months with price increases and decreases for retail and wholesale prices was roughly equal across all grades of gasoline.

\footnotetext{
11toneycutt (1985), p. 108.

12 bid., p. 113.

13The unadjusted data are calculated by the U.S. Bureau of Labor Statistics and reported in the U.S. Energy Intorma. tion Agency's Monthly Energy Review. These prices include all federal, state and local taxes paid at the time of sale. For the period 1978 forward, prices were collected from a sample of service stations in 85 urban areas selected to represent all urban consumers-about 80 percent of the total U.S. population. Service stations are selected initially, and on a replacement basis, in such a way that they represent the purchasing habits of the Consumer Price Index population. Service stations in the current sample include those providing all types of service (i.e., ful, mini and seif-serve). See Monthly Energy Review, February 1989 , p. 106. Retail prices are collected at dif ferent stations during the month of estimation.

${ }_{14}^{14}$ Taxes were removed from the retail price using information provided in the U.S. Department of Energy's Petroleum Marketing Monthly. Federal and state motor fuel taxes are reported by the agency about twice a year (generally those effective on January 1 and July 1).

${ }^{15}$ Handling the tax rate changes in this manner could bias the results because tax rate changes that occur between reported tax rate changes are not accounted for unit the next reporting month.

16 See the U.S. Department of Energy's Petroleum Marketing Annual and the Petroleum Marketing Monthly. This price series is based on information provided to the Energy
}

The retail prices used are tax-adjusted U.S. City Average Retail Prices of Motor Gasoline. ${ }^{13}$ The prices used were reduced by the sum of the federal gasoline tax and a simple average of the 50 states' gasoline tax. ${ }^{14}$ No attempt was made to interpolate tax rates between months where tax rates were actually observed. The most current reported tax rates were used until new tax data became available. ${ }^{15}$

Wholesale prices are those from data referred to as "Sales for Resale."16 These are sales of refined petroleum products to purchasers who are "other-than-ultimate consumers." This series does not include refined petroleum product sales made directly to end users, such as agriculture, industry and utility consumers or sales made by refiners to company-operated retail outlets. Wholesale prices are reported exclusive of taxes.

\section{FGU}

Equation 4 was estimated for premium, unleaded regular and leaded regular gasoline. Preliminary estimates of lag lengths were selected using Akaike's (1970) Final Prediction Error (FPE) criterion. ${ }^{17}$ The FPE procedure used to estimate the "best" lag length requires the user to specify a maximum lag length. For our data, the lag lengths selected by the FPE procedure were sensitive to alternative maximum lag lengths. ${ }^{ \pm 8}$

Information Agency by firms responding to two separate surveys. The first survey, ElA-782A, "Refiners'/Gas Plant Operators' Monthy Petroleum Product Sales Report," is sent to a census of about 200 refiners and gas plant operators. The second survey, ElA-7828, "Reseller/Re." tailers' Monthly Petroleum Product Sales Report," is sent to about 3,000 resellers and retallers. Some of the firms in this survey are replaced on an annual basis. In both surveys, firms are surveyed on a monthly basis and are asked to report prices on a monthly volume-weighted basis.

17Batten and Thornton (1984) note that the FPE criterion attempts to balance the "risk" due to bias when shorter lag lengths are selected against the "risk" due to the increase in variance when longer lag lengths are chosen. Thornton and Batten (1985) point out that the FPE procedure gives relatively more importance to a lack of bias than efficiency They argue that the procedure is asymptotically inefficient in that, on the average, it selects lags that are too long in large samples.

18Maximum lag lengths of six, nine and 12 months were specified in the FPE procedure. Results for the six-morth and nine-month maximum were identical, although the 12 month maximum model chose longer WI lags (10 months) for premium and unleaded regular gasoline. Lag lengths suggested by the six-and nine-month maximum lag length models were used in estimating equation 4. 
Table 1

\section{Symmetry Tests For Different Grades of Gasoline from January 1983- December 1990}

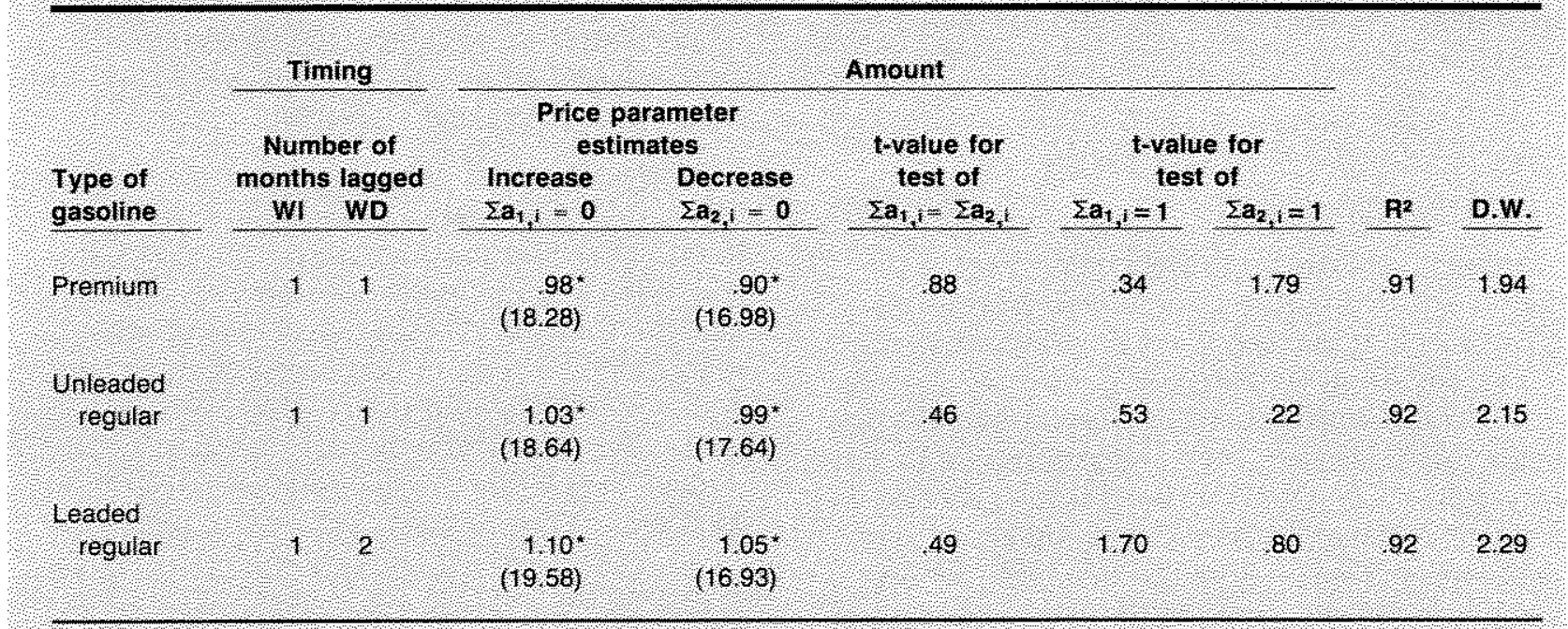

Nole Numbers in parentheses are the absolute values of the trstatstics.

indicales statistical significance at the 5 percent level?

After estimating the model with the lag lengths suggested by the FPE procedure, F-tests and t-tests were performed to see if any of the lags (incrementally or as a group) could be eliminated as statistically insignificant. Only the significant lags are reported below. ${ }^{13}$ Significant first-order autocorrelation was not present in any of the estimated equations.

\section{Timing Symmetry}

The ordinary least squares estimates for equation 4 are summarized in table 1. Lag lengths used for periods of wholesale price increases were the same across all grades of gasoline; lag lengths used for periods of wholesale price decreases were the same for premium and unleaded regular. Leaded regular gasoline had a slightly longer lag length for wholesale price decreases. These models suggest that wholesale price increases affect retail prices for two months (the initial month plus a lagged month). Similarly, wholesale price decreases affect the retail price of premium and unleaded regular gasoline for two months. For leaded regular gas- oline, however, wholesale price decreases affect the retail price for three months. Thus, the hypothesis that the length of time in which retail prices completely respond to a wholesale price change is symmetric cannot be rejected for premium and unleaded regular gasoline but can be for leaded regular gasoline.

\section{Amonnt Symmetry}

Since the impact of the wholesale price change on the retail price is distributed over more than one month, the test for symmetry in the amount of pass-through examines whether the total response to a wholesale price increase is equal to the total response to a wholesale price decrease. In other words, is $\sum_{i=0}^{p} a_{1, i}=\sum_{i=0}^{i} a_{2, i}$ ? The results of this test are shown in table 1 . For all grades of gasoline, the cumulative response of retail prices to a wholesale price increase is no different from that to a wholesale price decrease. In addition, the hypotheses that $\sum_{i=0}^{1} a_{1, i}=1$ and $\sum_{i=0}^{q} a_{2, i}=1$ cannot be rejected for any grade of gasoline. This implies that wholesale price decreases are fully passed along to

\footnotetext{
19The reported lag lengths are those suggested by the FPE criterion except for premilum's WI (for which the FPE procedure suggested a lag length of three months), and unleaded's WD (for which the FPE procedure suggested a lag length of two months).
} 
Table 2

The Pattern of Retail Gasoline Price Response

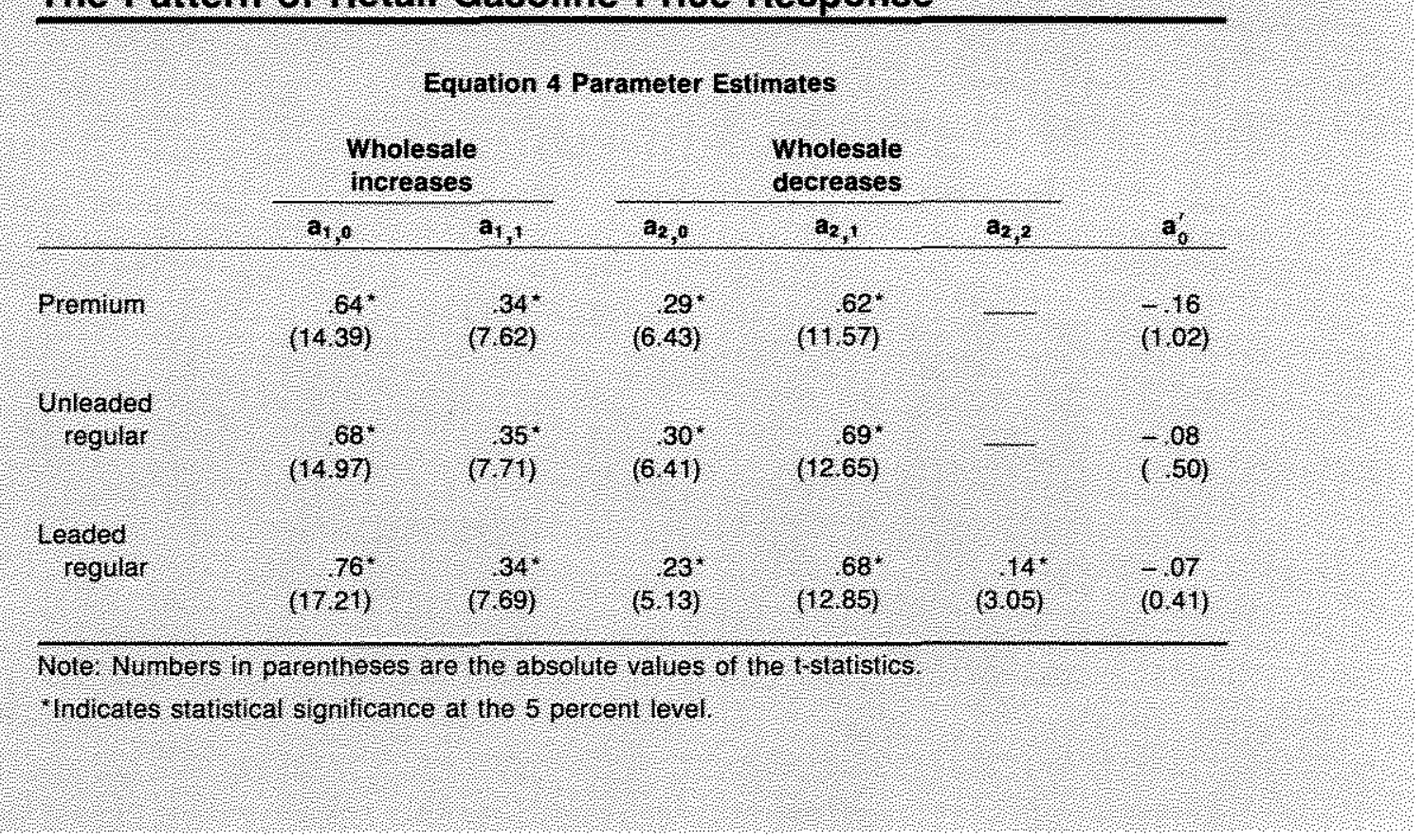

consumers, as are wholesale price increases. In short, the hypothesis that the amount of passthrough in the retail gasoline market is symmetric cannot be rejected for the period of investigation.

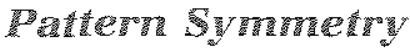

Even though the time it takes retail prices to respond fully to wholesale price changes and the total amount that retail prices respond to wholesale price changes are symmetrical, there is a difference in the pattern of response to wholesale price increases and decreases. The coefficient estimates for equation 4 are graphically shown, by grade of gasoline, in figure 3 . For wholesale price increases, the largest retail response occurs in the current month for all grades of gasoline. But, for wholesale price declines, retall prices respond relatively little in the first month, and make their largest adjustment in the month following the wholesale price decline.

Using the premium gasoline model as an example, a direct interpretation of the coefficients, as reported in table 2 , is as follows: a 10 -cent increase in the wholesale price leads to a 6.4 - cent increase in the retail price during the initial month, while a 10 -cent wholesale price decline leads to a 2.9-cent decline in the initial pertod. For premium gasoline, there is about a 3.5 -cent per gallon difference in the amount that the retail price responds to a 10-cent wholesale price increase and decrease during the initial month. For unleaded regular and leaded regular, the difference is about 3.8 cents and 5.3 cents per gallon for every 10 cent change in the wholesale price, respectively. Indeed, a test for equality of the $a_{1,0}$ and $a_{2,0}$ coefficients is rejected for all grades of gasoline, indicating asymmetry in the amount of price response during the initial month of the wholesale price change. Wholesale gasoline price increases are passed along more fully in the initial month than are wholesale price decreases. The amount of the total retall adjustment occurring in the initial month ranges from 65 percent to 69 percent for wholesale price increases, and from 22 percent to 32 percent for wholesale price decreases. ${ }^{20}$

During the second month, between 31 percent and 35 percent of the total retail adjustment occurs for wholesale price increases, and between

20The initial month percent response, for a wholesale price increase was calculated as $\left[a_{1,0} /\left(\sum_{i=0}\left|a_{1, j}\right|\right)\right] \star 100$. 
Figure 3

Asymmetry in the Pattern of Retail Price Response

\section{(Estimated Coefficients for Equation 4)}

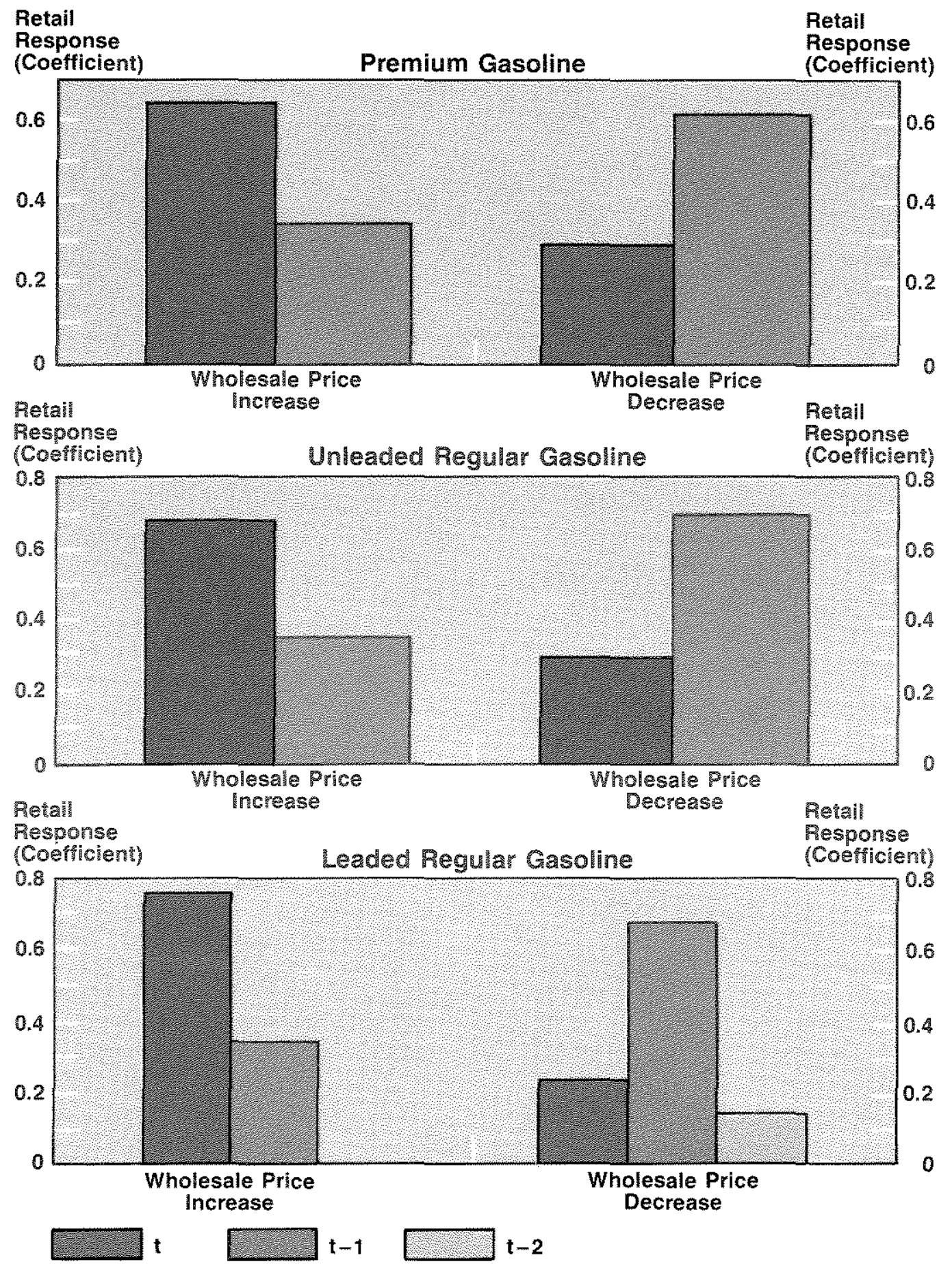


65 percent and 70 percent for wholesale price decreases. The hypothesis that $\mathrm{a}_{1,1}=\mathrm{a}_{2,1}$ is rejected for all grades of gasoline, indicating asymmetry in the amount of price response during the month following a wholesale price change. For leaded gasoline, a third month is needed before the impact of a wholesale price decline is fully reflected in the retail price.

\section{CONGUUSTON}

This paper has tested for symmetric retail gasoline price responses to changes in wholesale gasoline prices. The results show that the length of time in which a wholesale price increase is fully reflected in the retail gasoline price is the same as that of a wholesale price decrease for premium and unleaded regular gasoline. Wholesale gasoline price increases for leaded regular gasoline are passed along to the consumer more quickly than price decreases. Although the time in which retail prices fully respond to increases and decreases in wholesale prices is the same for both premium and unleaded gasoline, the pattern of retail price adjustment is such that consumers will experience the bulk of a wholesale price change sooner for price increases than they do for decreases. However, contrary to the popular belief that consumers do not benefit from wholesale gasoline price decreases, wholesale gasoline price decreases are eventually passed along to consumers as fully as are wholesale gasoline price increases.

\section{PRERTENCES}

Akaike, Hirotugu. "Statistical Predictor Identification," Annals of the Institute of Statistical Mathematics (1970), pp. 203-17.

Anderson, Robert O. Fundamentals of the Petroleum Industry (University of Oklahoma Press, 1984).

Batten, Dallas S., and Daniel L. Thornton. "How Robust Are the Policy Conclusions of the St. Louis Equation?: Some Further Evidence," this Review (June/suly 1984), pp. 26-32.

Bils, Mark. "The Cyclical Behavior of Marginal Cost and Price." The American Economic Review (December 1987), pp. 838-55.

Boyd, Milton S., and B. Wade Brorsen. "Price Asymmetry in the U.S. Pork Marketing Channel," North Central Journal of Agricultural Economics (1988), pp. 103-09.

"Business Bulletin;" The Wall Street Journal, August 3, 1989.

Crudele, John. "Gasoline Up, O\# Down in Price Paradox," St. Louis Post-Dispatch, June 19, 1990.
Domowitz, lan, R. Glenn Hubbard, and Bruce C. Petersen. "Market Structure and Cyclical Fluctuations in U.S. Manufacturing," The Review of Economics and Statistics (February 1988), pp. 55-66.

Dougher, Rayola S., and Russell O. Jones. Gasoline Distribution and Service Station Margins: An Assessment of EPA Assumptions and Implications for Methanol (American Petroleum Institute, September 1990).

Fraser, R.W. "Uncertainty and the Theory of Markusp Pricing," Bulletin of Economic Research (1985), pp. 55-64.

Hahn, William F. "Price Transmission Asymmetry in Pork and Beef Markets," The Joumal of Agricultural Economics Research (1990), pp. 21-30.

Heien, Dale M. "Markup Pricing in a Dynamic Model of the Food Industry," American Journal of Agricultural Economics (1980), pp. 11-18.

Honeycutt, T. Crawford. "Competition in Controlled and Uncontrolled Gasoline Markets," Contemporary Policy Issues (Spring 1985), pp. 105-18.

Kinnucan, Henry $W$, and Olan D. Forker. "Asymmetry in Farm-Retail Price Transmission for Major Dairy Products," American Journal of Agricultural Economics (1987), pp. 285-92.

Mckenzie, Richard B. "Did 'Big Oil' Gouge Prices?" The Journal of Commerce, March 6, 1991, p. 8A.

Morrison, Catherine J. "Markups in U.S. and Japanese Manufacturing: A Short Run Econometric Analysis," Working Paper Series No. 2799, National Bureau of Economic Research, Inc. (1988).

Pick, Daniel H., Jeffrey D. Karrenbrock, and Hoy F. Carman. "Price Asymmetry and Marketing Margin Behavior: An Example for California-Arizona Citrus," Agribusiness, Vol. 6 , No. 1, (1990), pp. 75-84.

Shribman, David, and Michel McQueen. "Office-Seekers Revive 1970s Campaign Strategy of Bashing Oil Companies Over Spike in Prices;" The Wall Street Journal, August 9,1990 .

Solomon, Caleb. "Gasoline Prices Resist Crude Behavior," The Wall Street Journal, May 2, 1990.

"Ol Companies Bend in Wake of Public Outcry." The Wall Street Journal, August 9, 1990.

Thornton, Daniel L., and Dallas S. Batten. "Lag-Length Selection and Tests of Granger Causality Between Money and Income," Journal of Money, Credit, and Banking (May 1985): pp. $164-78$.

U.S. Department of Energy, Energy Information Agency. Monthly Energy Review, Washington, D.C., various issues.

Petroleum Marketing Annual, Washington D.C., various issues.

Petroleum Marketing Monthly, Washington D.C. various issues.

Wald, Matthew L. "Prices of Gasoline Fail to Reflect Drop in Cost of Crude Oil," New York Times, July 2, 1990.

Ward, Ronald W. "Asymmetry in Retail, Wholesale, and Shipping Point Pricing for Fresh Vegetables," American Journal of Agricultural Economics (1982), pp. 205-12.

Wolfram, Rudoiph. "Positivistic Measures of Aggregate Supply Elastictites: Some New Approaches-Some Critical Notes," American Journal of Agricuitural Economics (May 1971), pp. 356-59. 